\title{
PERLINDUNGAN KONSUMEN TERHADAP PRODUK CACAT DALAM PERSPEKTIF FIQIH JUAL BELI
}

\author{
Aulia Muthiah \\ Fakultas Hukum Universitas Achmad Yani Banjarmasin, Jl. Jendral Achmad Yani Km, 5,5 Komp. \\ Stadion Lambung Mangkurat Banjarmasin \\ E-Mail: auliamuthiah@gmail.com
}

\begin{abstract}
Abstrak: Perlindungan konsumen bertujuan untuk memberikan kenyamanan antara pelaku usaha dengan konsumen dengan cara mengatur hubungan yang harmonis antara keduanya, dalam kegiatan bertransaksi sering sekali terjadi kesalahan, salah satunya adalah penjual produk yang rusak atau cacat. Produk yang cacat ini tentu akan merugikan konsumen sehingga dalam hal ini sangat urgen untuk diketahui bagaimana sesungguhnya fiqih jual beli mengaturnya, karena fiqih merupakan suatu dasar tuntunan seseorang dalam menjalankan aturan-aturan kehidupan. Tulisan ini merupakan bentuk analisis yang menggambarkan bagaimana wujud dari perlindungan terhadap konsumen ketika dalam proses jual belinya mendapatkan produk cacat yang dianalisis dari kajian hukum Islam spesisialisasinya adalah fiqih jual beli. Hasil dari analisis ini menyatakan bahwa Fiqih sebagai suatu tuntunan melarang Semua pelaku usaha untuk menjual barangnya yang cacat, tanpa menjelaskan kepada pembeli tentang kecacatan barang dagangan tersebut. Sehingga solusi yang ditawarkan fiqih jual beli dalam permasalahan ini adalah dengan cara melakukan hak khiyar aibi dimana ketentuannya adalah konsumen boleh mengembalikan barang yang dibelinya apabila pada barang tersebut terdapat suatu kecacatan, yang mengurangi kualitas barang atau mengurangi harganya. Namun jika konsumen sudah mengetahui kecacatan suatu produk tersebut kemudian dia ridha dengan hal tersebut maka akad jual beli tetap bisa dilanjutkan.
\end{abstract}

Kata kunci: Perlindungan konsumen, produk cacat, fiqih jual beli

\begin{abstract}
Consumer protection aims to provide comport between seller with consumer viz bay setting agood relationship between seller with consumer, in the transaction activity some times errors accur, example sales of defective product. The product is defective will harm consumers so it is very important to know haw the fiqih sale and purchase set it, because fiqih it is the basis of one's guidance in living the rules of live. This writing is a from of analysis illustrates, how to protect consumers when in the process of buying which is analyzed by fiqih sale and purchase. The results of this analysis state that fiqih is a guide, forbid all trade to sell defective product without explaining to consumers a bout defective products. The solution offered fiqih sale and purchase in this issue by way of application of rights khiyar aibi. The provisions are the consumer may return the product that has been purchased, if the product has a defect that reduces its quality or price, but if consumers all ready know the defect of the product and he is willing then the sale and purchase agreement can be continued.
\end{abstract}

Key word: Consumer protection, defective product, fiqih sale and purchase

\section{Pendahuluan}

Suatu perkembangan yang sangat

luar biasa pesatnya yaitu pertumbuhan

dan perkembangan dunia usaha baik itu

dalam skala nasional maupun

intenasional. Jika pada masa lalu pihak pelaku usaha dipandang sebagai pihak yang sangat berjasa dalam pemenuhan semua keperluan manusia, dan juga pelaku usaha dianggap sebagai pihak yang mampu memajukan perekonomian suatu

Negara. Namun dalam berjalannya waktu 
manusia menyadari bahwa tanpa yang mengatur kepentingan konsumen konsumen pelaku usaha juga tidak akan dengan pelaku usaha. Tujuannya adalah mampu berjaya. Sehingga berangsur- agar tidak ada pihak yang dirugikan akibat angsur konsumen menyadari bahwa dari perbuatan curang salah satu pihak. mereka juga bagian dari kesuksesan dari pelaku usaha.

Perlindungan konsumen

Perlindungan terhadap konsumen merupakan salah satu kajian hukum yang paling dinamis baik dari sisi hukum positif maupun hukum Islam. Hal ini terjadi karena Hukum Perlindungan Konsumen bersinggungan langsung dengan aktifitas perekonomian yang berkembang secara signifikan seiring dengan perkembangan zaman dan kemajuan teknologi.

Pengaruh globalisasi yang menyebabkan konsumen diberikan banyak pilihan, pelaku usaha semakin dituntut untuk memproduksi barang/jasa yang sesuai keperluan masyarakat dan juga sukai, sehingga terkadang pelaku usaha tidak memperhatikan kualitas suatu produk baik barang/jasa, dalam hal ini tentu konsumen menjadi dirugikan. Jadi diperlukanlah aturan yang akan menjembatani antara kepentingan pelaku usaha dengan kepentingan konsumen. Kepentingan kedua belah pihak ini harus terpenuhi yaitu dengan adanya hukum merupakan bagian yang tidak dapat terpisahkan dari kegiatan bisnis yang sehat. Dalam kegiatan bisnis yang sehat terdapat keseimbangan perlindungan hukum antara konsumen dengan pelaku usaha. Tidak adanya perlindungan yang seimbang menyebabkan konsumen berada pada posisi yang lemah, apalagi jika produk yang dihasilkan merupakan jenis produk yang terbatas, sehingga pelaku usaha dapat menyalahgunakan posisinya yaitu dengan cara memonopoli produksi dan pemasaran, hal ini tentu saja akan sangat merugikan konsumen.

Dalam kajian ilmu fiqih seorang ahli fiqih yang bernama Yusuf Qaradawi beliau berpendapat bahwa ada dua ranah yang cukup terbuka dan mendesak untuk dilakukan ijtihad di era sekarang ini untuk menemukan jawaban dan landasan hukum, yaitu; pertama pada kajian aktivitas ekonomi dan bisnis, kedua pada bidang sains dan kesehatan. Dengan adanya pendapat seorang ahli fiqih ini 
penulis mencoba menganalisis fiqih jual beli dalam konteks perlindungan terhadap hak-hak konsumen.

Ilmu fiqih yang mengatur hubungan antara konsumen dengan pelaku usaha, salah satunya adalah tentang hak dan kewajiban yang harus dilaksankan oleh pelaku usaha dan konsumen. Hubungan ini menjadi harmonis dengan aturan hukum baik dari sisi ilmu fiqih. Sehingga dengan penerapan aturan fiqih ini akan terjalin hubungan baik antara konsumen dengan pelaku usaha, yaitu hubungan yang tidak merugikan salah satu pihak, dan menguntungkan kedua belah pihak, sehingga terjalin hubungan yang saling ridha antara keduanya.

Dalam memenuhi hak dan kewajiban antara pelaku usaha dengan konsumen biasanya aka nada beberapa masalah yang akan mereka hadapi salah satunya adalah masalah penyediaan produk yang baik, tidak sedikit konsumen yang kecewa dengan produk yang sudah mereka beli, terkadang mereka mendapati produk yang mereka beli dalam keadaan rusak atau cacat, sehingga konsumen merasa kecewa dan tentu saja produk yang rusak atau cacat ini merugikan pihak konsumen. Dasar dalam jual beli adalah keridhaan kedua belah pihak yaitu konsumen dan pelaku usaha, jika konsumen dirugikan tentu saja pihak konsumen tidak ridha dengan jual beli yang sudah dilakukan tadi. Jadi jika keridhaan ini tidak terwujud maka apakah jual beli ini dapat dinyatakan sebagai akad yang sah. Kerugian yang diderita oleh konsumen tentu saja harus diganti oleh pelaku usaha, tentu dalam hal ini diperlukan proses ganti rugi tersebut.

Berdasarkan uraian yang ada pada pendahuluan di atas maka permasalahan yang akan diteliti adalah berkaitan dengan aturan hukum tentang tanggung jawab pelaku usaha terhadap kerugian yang diderita oleh konsumen, rumusan masalah adalah sebagai berikut:

1. Bagaimanakah hukum perlindungan konsumen dalam persfektif fiqih jual beli?

2. Bagaimanakah fiqih jual beli mengatur perlindungan konsumen terhadap produk cacat?

Dua pertanyaan tersebut akan ditemukan dalam penelitian ilmiah ini. 
Perlindungan Konsumen dalam Tata Aturan Fiqih Jual Beli

Sejarah perkembangan hukum Islam pada masa Nabi SAW merupakan cikal bakal pertumbuhan hukum Islam pada masa sekarang ini. Perkembangan hukum Islam membangkitkan semangat masyarakat menuju pencerahan kehidupan bersama dan menjunjung tinggi nilai-nilai kemanusiaan yang sudah sepantasnya diperoleh mereka dari kebijakan-kebijakan pemimpinnya.

Kata hukum Islam tidak ditemukan sama sekali di dalam al-Qur'an dan literatur hukum dalam Islam, yang ada dalam al-Qur'an adalah kata syari'ah, fiqh, hukum Allah dan yang seakar dengannya. Kata-kata hukum Islam merupakan terjemahan dari "Islamic Law" dari literatur Barat. Dalam penjelasan tentang hukum Islam pada literatur Barat ditemukan definisi hukum Islam yaitu: keseluruhan kitab Allah yang mengatur kehidupan setiap muslim dalam segala aspeknya. ${ }^{1}$ Berdasarkan definisi ini arti

\footnotetext{
1 Joseph Schacht, 1964, An Introduction to Islamic Law, Oxford: University Press, hlm. 1

2 Amir Syarifuddin, 1992, Pengertian dan Sumber Hukum Islam, dalam Falsafah Hukum Islam, Jakarta: Bumi Aksara, hlm. 14.

http://dx.doi.org/10.18592/sy.v18i2.2286
}

hukum Islam lebih dekat dengan pengertian syariah.

Secara sederhana Amir Syarifudin mendefinisikan: "Hukum Islam adalah seperangkat peraturan berdasarkan wahyu Allah dan Sunnah Rasul tentang tingkah laku manusia yang diakui dan diyakini berlaku dan mengikat semua yang beragama Islam"2. Jadi Hukum Islam mencakup Syariah dan Fiqih.

Hasbi Asy-Syiddiqy memberikan definisi hukum Islam dengan "koleksi daya upaya fuqaha dalam menerapkan syari'at Islam sesuai dengan kebutuhan masyarakat".Pengertian hukum Islam dalam definisi ini mendekati kepada makna fiqih. ${ }^{3}$ Pengertian hukum Islam dalam definisi ini mendekati kepada makna fiqih.

Secara terminologis kata fiqih biasanya didefinisikan yaitu; "pengetahuan tentang hukum-hukum syara' yang bersifat amaliyah yang disimpulkan dari dalil yang sudah terperinci”. Jadi fiqih adalah pengetahuan atau pemahaman terhadap hukum-

\footnotetext{
3 Muhammad Hasbi Ash-Shiddiqy, 1993
}

Falsafah Hukum Islam, Jakarta: Bulan Bintang, hlm. 44 
hukum syara' yang sifatnya amaliyah. kesehariannya salah satu interaksi yang Pengetahuan tersebut diperoleh melalui biasa mereka lakukan adalah jual beli demi dalil yang sudah terperinci. Hukum di sini memenuhi keperluan hidup mereka. berarti kitabullah atau ungkapan yang Dalam transaksi jual beli akan ada pelaku berasal dari Allah Swt, terkait dengan usaha dan konsumen. Maka dari itu perilaku orang mukallaf (cakap hukum). diperlukan aturan untuk konsumen adanya klausul hukum syara' ini untuk dengan pelaku usaha agar terjalin membatasi bahwa fiqih tidak hubungan yang harmonis antar membicarakan tentang hukum alam, konsumen dengan pelaku usaha. hukum adat ataupun hukum positif, Hubungan yang saling menguntungkan melainkan suatu ketentuan yang berasal dan tidak akan merugikan salah satu dari Allah Swt dan Rasullulah Saw. pihak.

Subjek dari kajian fiqih ini adalah perilaku mukallaf. Perilaku mencakup perilaku hati, seperti niat mencakup perkataan seperti bacaan, dan mencakup tindakan, jadi perilaku mukallaf ini harus sesuai dengan hukum syara', baik berupa kewajiban dan anjuran untuk melakukan (wajib dan mandub). Kewajiban atau anjuran untuk meninggalkan (haram dan makruh), ataupun yang bersifat pilihan, boleh melakukan atau meninggalkannya (mubah). ${ }^{4}$

Setiap hari manusia selalu berinteraksi dengan sesamanya, banyak kegiatan yang dilakukan dalam

Hubungan konsumen dan pelaku usaha merupakan hubungan manusia dengan manusia dalam kehidupan sosial, untuk menjaga hubungan ini maka diperlukan seperangkat aturan agar hubungan ini selalu terjalin harmonis. Konsumen adalah pihak yang memerlukan suatu produk (barang/jasa) yang terkadang kedudukannya dianggap lemah sehingga diperlukan suatu aturan yang akan memberikan perlindungan terhadap konsumen.

Perlindungan terhadap konsumen adalah hal yang sangat penting dalam kajian ilmu fiqih. Menurut pandangan

4 Imam Mustafa, 2016, Fiqib Mu'amalah Kontemporer, Jakarta: PT RajaGrafindo Persada $\mathrm{h} \operatorname{lm} 5$ 
Islam perlindungan konsumen bukan hanya sebagai hubungan keperdataan melainkan juga berhubungan dengan kepentingan publik secara luas. Selain itu menyangkut juga hubungan antara manusia dengan Allah Swt. Dalam konsep syariah perlindungan atas tubuh berkaitan dengan hubungan vertikal (manusia dengan Allah) dan hubungan horizontal (manusia dengan manusia). Hubungan konsumen dengan pelaku usaha terdapat dalam kajian ilmu fiqih. Interaksi konsumen dengan pelaku usaha adalah dalam jual beli, sehingga dalam hal hubungan antara konsumen dengan pelaku usaha memerlukan suatu aturan yang biasa disebut dengan fiqih jual beli.

Fiqih jual beli mengatur tentang perilaku para pelaku usaha dan konsumen berdasarkan hukum syara', dan mengatur hubungan hukum antara para pihak dalam transaksi jual beli tidak boleh bertentangan dengan ketentuan hukum syara', yang bersumber dari Al-Qur'an, hadis dan ijtihad ulama. Para ulama meletakan/memposisikan kitab jual beli (buyu) setelah kitab ibadah, karena ibadah merupakan aturan interaksi para hamba dengan sang khaliq, sedangkan jual beli aturan interaksi manusia dengan sesama, dan juga karena jual beli lebih banyak terkait dengan interaksi sosial kemanusian, hal ini disebabkan karena manusia memerlukan makanan, minuman, pakaian, tempat tinggal dan lainnya. Jual beli merupakan cakupan yang luas dalam kehidupan, karenanya para ahli hukum menjadikan jual beli setelah bagian dari ibadah. Lafaz bayu' merupakan bentuk jama' (plural) dari bai' yang bermakna jual beli. Hukum asal dari jual beli ini adalah halal. Dengan landasan ini maka jika ada yang memandang keharaman suatu jual beli, wajib mendatangkan dalil yang mengharamkannya.

Menurut kajian ilmu fiqih jual beli, melindungi hak-hak manusia sebagai masyarakat merupakan kewajiban Negara, salah satunya memberikan perlindungan terhadap konsumen dan juga memperhatikan setiap produk yang dikelola oleh pelaku usaha. Kajian fiqih tentang perlindungan konsumen secara eksplisit tidak ada aturan yang jelas menyebutkan perlindungan terhadap konsumen, namun kita dapat memahaminya dari perjalanan sejarah 
para Nabi yang Allah ceritakan di dalam Al-Quran.

Tentang hak-hak konsumen yang harus dilindungi terdapat pada cerita Nabi Syu'aib yang diutus untuk menyampaikan ajaran Allah kepada suatu kaum yang disebut dengan kaum Madyan ${ }^{5}$. Penduduk Madyan berprofesi sebagai pedagang dan petani yang mengalami kesesetan yaitu mereka melakukan penyembahan terhadap hutan, dan yang lebih sesat lagi adalah dalam memenuhi hajat penghidupannya, mereka melakukan kejahatan secara merata. Kehidupan mereka kicuh mengicuh, serta suka memperdayakan temannya sendiri untuk mendapat keuntungan. Jika mereka menimbang dagangan selalu mencari akal agar timbangan itu merugikan pihak lain dan menguntungkan pihaknya sendiri, sebaliknya, jika orang lain yang menimbang dagangan, dengan segala akalnya yang busuk, mereka jadikan agar dapat menguntungkan pihaknya dan merugikan pihak lain.

5 Madyan adalah nama salah seorang putra nabi Ibrahim as yang kemudian menjadi nama kabilah terdiri atas anak cucu keturunan madyan. Kabilah ini berdiam disuatu tempat yang akhirnya di namakan sebagai nama kota dan terletak di dekat pantai Laut Merah di tenggara gunung Sinai.
Dengan jalan demikianlah mereka mendapatkan harta kekayaan, yaitu dengan jalan yang tidak halal dan cara yang tidak sewajarnya, kehidupan mereka selalu merugikan pihak lain, begitu pula perjuangan mereka memang semata-mata ditujukan untuk merugikan pihak lain. Sehingga dengan kesesatan yang mereka lakukan ini Allah mengutus Nabi Syu'aib dengan membawa ajaran agama yang benar dari Allah, serta dikuatkan dengan wahyu dan mu'jizat. Nabi Syu'aib membawa mereka kepada menyembah Allah dan menjauhi segala tipu muslihat yang merugikan pihak lain, namun mereka tidak mau mendengarkan seruan Nabi Syu'aib bahkan mereka menentang dengan alasan yang dibuat-buat, ${ }^{6}$ yang akhirnya kaum madyan ini dihancurkan oleh Allah dengan siksa yang Allah datangkan kepada mereka, yaitu berupa gempa yang menjadikan penduduk madyan ini menjadi mayat-mayat yang bergelimpangan di dalam rumah-rumah mereka.

Kawasan ini terletak di daerah Yordania yang berbatasan dengan Palestina.

${ }^{6}$ Bey Arifin, 2015, Rangkeaian Cerita AlQur'an Kisah Nyata Penegub Iman, Jakarta: Zahira, hlm 186 
Berdasarkan cerita ini maka maka ayat ini secara tegas memerintahkan sesungguhnya Allah telah memberikan kepada pelaku usaha untuk bersikap jujur peraturan yang tujuannya memberikan dalam menjalankan usaha perlindungan kepada konsumen yaitu; perdagangannya untuk mencapai keadilan diperlakukan secara baik dan jujur oleh antara manusia, dan untuk menghindari pelaku usaha hal ini dapat kita pelajari perbuatan khianat yaitu mengambil hak pada surah Al-A'raf ayat 85 yaitu:

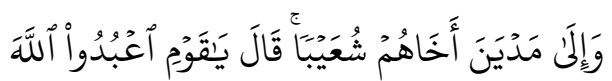

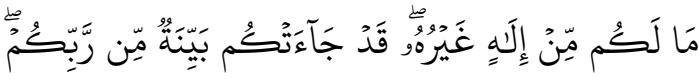

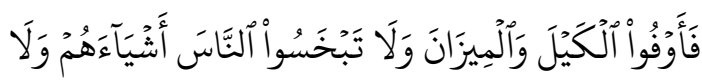

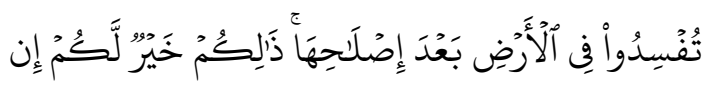
كُنتُم مَؤُمِنِينَ

"Dan (kami telah mengutus) kepada penduduk madyan saudara mereka syu'aib. Ia berkata: hai kaumku, sembahlab Allab sekali-kali tidak ada Tuban bagimu selain-Nya. Sesunggubnya telah datang kepadamu bukti yang nyata dari Tuhanmu. Maka sempurnakanlah takaran dan timbangan dan janganlah kamu kurangkan bagi manusia barang-barang takaran dan timbangannya, dan jangamlah kamu membuat kerusakan di muka bumi sesudah Tuban memperbaikinya. Yang demikian itu lebih baik bagimu jika betul-betul kamu orang-orang yang beriman"

Berdasarkan ayat yang disebutkan di atas, hal ini merupakan peristiwa sejarah tentang sebuah konsep yang menyatakan bahwa hak-hak konsumen harus dilaksanakan dengan sepenuhnya, orang lain tanpa hak, karena setiap manusia akan diminta pertanggung jawaban mereka tentang harta yang diperoleh kelak di akhirat.

Kejujuran dalam bertransaksi sangat ditekankan pada ayat ini karena pelaku usaha yang berbohong tentu tidak akan dipercaya konsumennya sehingga konsumen tidak akan bertansaksi untuk kedua kalinya karena mereka merasa khawatir jika mereka dibohongi kembali. Kebohongan yang dilakukan oleh pelaku usaha tentu akan merugikan konsumen.

Dalam kegiatan jual beli merugikan hak orang lain adalah perbuatan zalim yang dapat menimbulkan perasaan buruk di dalam jiwa orang yang terzalimi seperti perasaan dendam, iri hati bahkan putus asa dari keadilan dan kebaikan, yang mana semua itu adalah perasaan-perasaan yang dapat merusak suasana kehidupan, pergaulan dan hubungan-hubungan 
sosial, sehingga tidak ada keshalehan dalam kehidupan.

Setiap kesalahan akan berakibat pada suatu sanksi inilah yang disebut dengan hukum yaitu dimana hukum itu dilanggar maka tentu orang yang melanggar hukum ini akan mendapat sanksi. Begitu pula dengan kaum Madyan yang akhirnya di hukum oleh Allah dengan azab berupa gempa bumi yang membinasakan mereka semua tanpa tersisa. Jadi perilaku kaum Madyan adalah suatu perilaku yang melanggar hukum Allah. Sedangkan untuk zaman kita sekarang jika kita melakukan kezaliman terhadap orang lain maka tentu saja kita juga akan mendapatkan hukuman jika tidak di dunia maka tentu saja di akhirat kelak.

Sebagaimana penjelasan di atas, bahwa konsep tentang perlindungan konsumen di dalam kajian fiqih jual beli tidak disebutkan secara jelas, akan tetapi prinsip-prinsip perlindungan konsumen dapat kita temukan pada di dalam sumber-sumber hukum Islam seperti AlQur'an sebagaimana ayat yang sudah disebutkan di atas. Kemudian dapat juga kita temukan pada sumber hukum Islam yang kedua yaitu Hadis, hal ini dapat kita pelajari dari parktik dagang yang biasa Rasullah Saw lakukan. Beliau adalah pelaku usaha yang selalu menjaga dan memperhatikan hak-hak konsumen, sehingga beliau disenangi oleh konsumen. Konsep jual beli dalam pandangan Islam harus dilandasi dengan nilai-nilai dan etika yang menjunjung tinggi kejujuran dan keadilan dalam melakukan bisnis. Berdasarkan faktanya Rasulullah Saw telah banyak memberikan contoh untuk menjadi pelaku usaha yang adil dan jujur. Rasulullah Saw telah menetapkan prinsip-prinsip yang mendasar tentang pelaksanaan perdagangan yang adil dan jujur, salah satu prinsipnya adalah berkaitan dengan mekanisme pasar, dalam transaksi perdagangan kedua belah pihak (konsumen dan pelaku usaha) dapat saling menjual dan membeli suatu produk secara ikhlas tanpa ada campur tangan, intervensi dan paksaan dalam harga. ${ }^{7}$

Dalam berinteraksi Rasulullah Saw dikenal terpercaya, jujur dan menjaga diri

\footnotetext{
${ }^{7}$ Jusmaliani, 2008, Bisnis Berbasis Syariah, Jakarta: Bumi Akasara, hlm 55 
dari hal-hal buruk. Demikianlah perilaku beliau sehingga dijuluki dengan gelar alamin yang artinya terpercaya. Rasulullah Saw juga mengajarkan kepada para pelaku usaha untuk senantiasa bersikap baik, berkerja sama, amanah, tawakal, qana'ah, sabar dan tabah. ${ }^{8}$ Sebaliknya beliau juga menasihati agar pelaku usaha meninggalkan sifat kotor perdagangan yang hanya memberikan keuntungan sesaat, tetapi merugikan diri sendiri duniawi dan ukhrawi akibatnya kredibilitas hilang, konsumen kehilangan kepercayaan dan akhirnya kesempatan semakin menyempit.

Secara historis Islam membuktikan bahwa syariatnya mengajarkan bahwa setiap pelaku usaha tidak dibenarkan untuk melakukan sesuatu yang akan merugikan konsumen sebaliknya konsumen juga harus melakasanakan kewajibannya dengan baik. Islam mengajarkan untuk menjadi seorang pelaku usaha yang jujur dan adil setiap kali melakukan perdagangan kepada semua

\footnotetext{
${ }^{8}$ Muhammad Akram Khan, 1989, Economic Teaching of Prophet Muhammad, Islamabad: IIIE \& IPS, hlm 133
}

konsumen, agar konsumen juga akan merasa nyaman dalam berniaga.

Syaikh Muhammad Shalih AlUtsaimin memberikan nasihat kepada para pelaku usaha secara umum agar mereka bertaqwa kepada Allah swt dengan melakukan transaksi jual beli yang jujur dan penuh transparansi, jujur dari apa yang mereka jual, yaitu tentang karakter dan ciri-ciri barang yang diminta oleh para konsumen, dan transparan dari segala macam cacat yang ada pada barang, sehingga perdagangan antara pelaku usaha dengan konsumen saling diberkahi. 9

Berdasarkan penjelasan di atas maka kejujuran adalah prinsip jual beli yang harus dimiliki oleh setiap pelaku usaha, sifat ini juga akan mempertahankan usaha yang dimiliki oleh si pelaku usaha tersebut karena dengan kejujurannya ini maka para konsumen tentu akan merasa senang dan aman dalam melakukan transaksi dengan pelaku usaha yang jujur. Selanjutnya adalah setiap pelaku usaha hendaklah

\footnotetext{
9 Syaikh Muhammad Shalih Al-Utsaimin, et. al, (penerjemah Saptono Budi Satryo), 2008, Tanya Jawab Lengkap Permasalaban Jual Beli, Jakarta: Pustaka As-Sunnah, hlm 68
} 
bersikap santun terhadap semua konsumen demi memberikan pelayanan yang maksimal kepada konsumen. Jadi untuk menjadi pelaku usaha yang baik tentu saja kita dapat menjadikan Rasulullah sebagai tauladan kita.

\section{Cacat Produk dalam Persfektif Fiqih Jual Beli}

Kecacatan suatu barang dapat terjadi karena disebabkan dua hal, yaitu: Pertama, kecacatan barang yang sengaja dilakukan penjual, misalnya susu dicampur dengan air. Kedua, kecacatan barang yang terjadi dengan sendirinya. Jenis kecacatan ini adalah cacat bagian luar seperti hewan yang pincang, dan cacat bagian dalam seperti buah-buahan yang busuk di bagian dalamnya.

Dalam menentukan suatu produk dapat dikatakan sebagai produk cacat dapat dibedakan menjadi tiga kemungkinan yaitu:

1. Kesalahan produksi adalah keadaaan produk yang umumnya berada di baawah tingkat harapan konsumen, atau dapat pula cacat itu dapat membahayakan harta benda, kesehatan jiwa dan tubuh konsumen. Kesalahan produksi ini dapat dibedakan menjadi dua yaitu pertama; kesalahan yang meliputi kegagalan proses produksi, pemasangan produk, kegagalan pada sarana inspeksi, apakah karena kelalaian manusia atau ketidakberesan pada mesin yang serupa dengan itu. Kedua; produkproduk yang telah sesuai dengan rancangan dan spesifikasi yang dimaksudkan oleh pembuat, namun terbukti tidak aman dalam pemakaian normal

2. Cacat desain adalah cacat yang terjadi pada tingkat persiapan produk. Hal ini terdiri atas, desain, komposisi atau konstruksi.

3. Cacat peringatan atau instruksi, adalah berhubungan dengan pemasaran suatu produk, di mana keamanan suatu produk ditentukan oleh informasi yang diberikan kepada pemakai yang berupa pemberian label produk, cara penggunaan, peringatan atas risiko tertentu atau hal lainnya sehingga pelaku usaha dapat memberikan jaminan bahwa produk-produk 
mereka itu dapat diperguanakan sebagaimana dimaksudkan, sehingga pelaku usaha berkewajiban untuk memperhatikan keamanan produknya. Cacat informasi ini adalah jika suatu produk tidak dilengkapi dengan informasi peringatan atau instruksi penggunaan produk.

\section{Tanggung Jawab Pelaku Usaha} Terhadap Konsumen Cacat Produk

Perkembangan pesat kegiatan dunia usaha berkat kemajuan ilmu pengetahuan dan teknologi, tampaknya merupakan pendorong utama terciptanya doktrindoktrin baru dalam kajian hukum termasuk salah satunya adalah bentuk tanggung jawab pelaku usaha terhadap konsumen pada produk cacat yang telah dibeli atau dikonsumsi konsumen.

Pada dasarnya tanggung jawab produk cacat ini berbeda dengan tanggung jawab pelaku usaha pada umumnya. Tanggung jawab produk cacat terletak pada tanggung jawab cacatnya produk berakibat pada orang, orang lain

${ }^{10}$ Celina Tri Siwi Kristiyanti, 2001, Hukum Perlindungan Konsumen, Jakarta: Sinar Grafika hlm 104

http://dx.doi.org/10.18592/sy.v18i2.2286 atau barang lain, sedang tanggung jawab pelaku usaha karena perbuatan melawan hukum adalah tanggung jawab atas rusaknya atau tidak berfungsinya produk itu sendiri. ${ }^{10}$

Semakin canggih proses pembuatan produk dan tumbuh berkembangnya sistem pemasaran yang digunakan oleh para pelaku usaha, maka semakin sulitnya konsumen membuktikan kesalahan pelaku usaha. Jadi sebagai konsumen yang dirugikan disebabkan oleh produk cacat ini semakin tidak dapat dicari dan dibuktikan oleh konsumen, karena sesungguhnya yang mengetahui proses produksi suatu produk tentu saja adalah pelaku usaha itu sendiri. Setiap produk yang sampai ke tangan konsumen lazimnya didahului dengan jual beli.

Dalam hubungan akad jual beli maka kedua belah pihak dibebankan hak dan kewajiban. Kewajiban utama pelaku usaha adalah menyerahkan barangnya dan menanggungnya. Menyerahkan barang artinya memindahkan penguasaan atas barang yang dijual dari tangan penjual (pelaku usaha) kepada pembeli 
(konsumen), oleh karena itu penjual (pelaku usaha) masih wajib menyerahkan barang yang dijualnya kepada pembeli. Penyerahan dapat dilakukan bersamaan dengan pembayaran dari pembeli (konsumen), atau dalam waktu yang hampir sama, tetapi selalu terbuka kemungkinan untuk melakukan penyerahan pada waktu yang berbeda dengan saat tercapainya kesepakatan.

Sedangkan yang dimaksud dengan menanggung adalah kewajiban penjual (pelaku usaha) untuk memberi jaminan atas kenikmatan tentram dan jaminan dari cacat-cacat tersembunyi (bidden defects). Kewajiban menanggung kenikmatan tentram artinya bahwa penjual wajib menjamin bahwa pembeli tidak akan diganggu oleh orang lain dalam hal memakai atau mempergunakan barang yang dibelinya. Ini merupakan konsekuensi dari jaminan yang diberikan oleh penjual (pelaku usaha) kepada pembeli (konsumen) bahwa produknya adalah sungguh-sungguh miliknya sendiri yang bebas dari suatu beban dan tuntutan

${ }^{11}$ Subekti, 1987, Aneka Perjanjian, Bandung: Alumni, hlm 17

${ }_{12}$ Sulaiman Rasjid, 1998, Fiqih Islam, Bandung: Sinar Baru Algesindo, hlm 286 dari suatu pihak. ${ }^{11}$ Atas kewajiban menanggung ini, penjual (pelaku usaha) bertanggung jawab terhadap segala tuntutan dari pihak pembeli (konsumen) yang berkenaan dengan barang yang jualnya. Dengan adanya kewajiban menanggung ini, penjual (pelaku usaha) bertanggung jawab terhadap segala tuntutan konsumen yang berkenaan dengan produk yang dijualnya.

Dalam kajian fiqih jual beli menjalankan transaksi dikenal dengan istilah kbiyar artinya "boleh memilih antara dua, meneruskan akad jual beli atau mengurungkan (menarik kembali tidak jadi jual beli)" hukum khiyar ini ada agar kedua orang yang sedang bertransaksi jual beli dapat memikirkan kemaslahatan masing-masing lebih jauh agar tidak terjadi penyesalan di kemudian hari. ${ }^{12}$

Secara terminologis khiyar adalah hak pilih bagi salah satu atau kedua belah pihak yang melaksanakan transaksi atau membatalkan transaksi, baik pada kbiyar syarat, khiyar aibi, maupun khiyar ta'yin. ${ }^{13}$ Berdasarkan kompilasi hukum ekonomi

\footnotetext{
${ }^{13}$ Wahbah Zuhaili, 2007, Al-Fiqbul Islami wa Adillatubu, (terj. Abdul Hayyie Al-Kattani dkk), Jakarta: Gema Insani, hlm 197
} 
syariah, khiyar adalah hak pilih bagi penjual dan pembeli untuk melanjutkan atau membatalkan akad jual beli yang dilakukan. ${ }^{14}$ Hak kbiyar ditetapkan dalam syariat Islam bagi orang-orang yang melakukan transaksi jual beli agar tidak dirugikan dalam transaksi yang mereka lakukan, sehingga kemaslahatan yang dituju dalam suatu transaksi tercapai dengan sebaik-baiknya. Status khiyar, menurut ulama fiqih adalah disyariatkan atau dibolehkan karena suatu keperluan yang mendesak dalam mempertimbangkan kemaslahatan masing-masing pihak yang melakukan transaksi.

Larangan tentang keharaman menjual barang yang cacat ditegaskan di dalam hadis Rasulullah Saw yaitu:

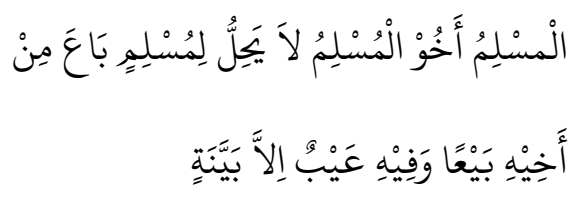

"Orang musilim adalah saudara orang muslim lainnya. Tidaklah halal bagi seorang muslim untuk menjual kepada saudaranya sesuatu yang memiliki cacat kecuali dia menjelaskannya"15

14 Pasal 20 ayat 8 Kompilasi Hukum Ekonomi Syari'ah

15 Diriwayatkan oleh Ibnu Majah di dalam sunan ibni majah, kitab Tijarat, hadis nomor 2246;
Semua pelaku usaha diharamkan untuk menjual barangnya yang cacat, tanpa menjelaskan kepada pembeli tentang kecacatan barang dagangan tersebut. Dalam transaksi jual beli barang cacat ini disebut dengan Khiyar aibi adalah suatu kasus ketika pembeli boleh mengembalikan barang yang dibelinya apabila pada barang tersebut terdapat suatu kecacatan, yang mengurangi kualitas barang atau mengurangi harganya. Menurut tradisi cacat pada barang ini umumnya dapat mengurangi kewajaran atau kenormalan barang dagangan. Khiyar aibi adalah hak untuk membatalkan atau meneruskan akad apabila ditemukan aib (cacat) setelah berlangsungnya akad, sedangkan pembeli tidak mengetahui tentang hal itu pada saat berlangsungnya akad, jadi pembeli boleh mengembalikan dan merusak akad bai' jika barang yang dibelinya terdapat cacat walaupun hal itu tidak disyaratkan.

$$
\text { Cacatnya suatu barang }
$$
menyebabkan rusaknya akad bai' sehingga pembeli boleh mengembalikan barang

Baihaqi di dalam Sunan Baihaqi, Jilid V, hlm 320; dan Thabrani di dalam kitab al-Kabir, Jilid XVII, hlm 317 
tersebut kepada penjual. Akan tetapi dan mengambil harga yang telah barang yang dapat dikembalikan jika dibayarkannya kepada penjual, atau kecacatannya memenuhi beberapa syarat mempertahankan barang dan mengambil yaitu:

1. Kecacatan tidak ditemukan pada dari penjual sebagian dari harga sesuai kebanyakan barang yang sejenisnya, jika ternyata pada kebanyakan barang yang sejenis ditemukan kecacatan maka tidak boleh dikembalikan.

2. Kecacatan suatu barang tidak bisa dihilangkan kecuali dengan bersusah payah, tetapi apabila cacat tersebut bisa dihilangkan dengan mudah maka barang tersebut tidak boleh dikembalikan.

3. Kecacatan sudah ada ketika barang masih menjadi milik penjual. ${ }^{16}$ Apabila akad terlaksana, sedangkan pembeli mengetahui adanya cacat, maka akad ini bersifat mengikat. Tidak ada khiyar bagi pembeli karena dia telah ridha. Namun jika pembeli tidak mengetahui adanya cacat, lalu dia mengetahuinya setelah akad maka akad itu sah, tetapi tidak besifat mengikat. Pembeli boleh memilih antara mengembalikan barang dengan kadar kekurangan yang ditimbulkan oleh cacat tersebut, kecuali apabila dia ridha kepada cacat tersebut atau didapatkan darinya sesuatu yang menunjukkan keridhaannya. Namun Jika pembeli menemukan cacat dan pembeli ini tidak menerima barang cacat tersebut, maka harus dikembalikan kepada penjual dan tidak boleh menahannya lalu meminta ganti rugi. Pembeli yang mengembalikan barang karena terdapat cacat padanya. Boleh mengambil uang pembayaran, kecuali jika tidak mungkin untuk dikembalikan dengan sebab terjadinya cacat yang baru. Penghitungan ganti rugi yang wajib diberikan kepada pembeli adalah dengan membandingkan harga barang antara waktu normal dengan waktu cacat dengan melihat harga pembayarannya.

Menurut mazhab Syafi'i seseorang yang membeli suatu barang, kemudian menemukan kecacatan maka boleh

16 Asmaji Muchtar, 2016, Dialog Lintas Maŗab Fiqh Ibadah \& Muamalah, Jakarta: Amzah, hlm 432 
dikembalikan jika kecacatannya terjadi sebelum dia menerima barang tersebut, baik cacat itu terjadi sebelum akad bai' atau setelahnya. Begitu juga jika cacat itu terjadi setelah diterima pembeli dan kecacatan itu disebabkan oleh cacat sebelumnya maka boleh dikembalikan, tetapi jika barang telah berada di tangan pembeli dan terjadi kecacatan yang baru, kemudian dia menemukan kecacatan yang lain terjadi ketika di tangan penjual maka pembeli tidak berhak mengembalikannya karena cacat yang baru tidak disebabkan oleh cacat yang lama, kecuali penjual rela akan kecacatan tersebut.

Menurut mazhab Hanbali seseorang yang membeli barang dan menemukan kecacatan pada barang tersebut maka dalam hal ini akan ada dua kemungkinan yaitu: pertama kecacatan terjadi sebelum diterima pembeli, dalam hal ini boleh dikembalikan baik cacat terjadi sebelum atau sesudah akad bai, baik pembeli mengetahuinya maupun tidak, kecuali tanggung jawab barang itu dibebankan pada pembeli. Kedua kecacatan berada di tangan pembeli ketika dia sudah menerimanya tanpa ada keberatan dan penjual sudah menunjukkan cacat itu, dalam hal ini pembeli tidak boleh mengembalikan dan penjual tidak bertanggung jawab. ${ }^{17}$

Adapun mengenai penjual yang mensyaratkan bebas dari kecacatan suatu barang dagangannya menurut mazhab Hanafi sah hukum jual belinya dengan menggunakan syarat bebas dari tanggung jawab barang cacat. Sedangkan menurut mazhab Maliki syarat bebas dari cacat yang ada dalam barang yang dibeli tidak bisa berfaedah, jika hal ini menjadi syarat maka tidak bisa bermanfaat bagi penjual, dan pembeli tidak bisa mengembalikan barang dengan sebab cacat. Mazhab Hanbali mengatakan, seseorang yang menjual barang dan mensyaratkan pada pembeli bahwa dia tidak bertanggung jawab atas cacat yang terjadi setelah akad sebelum diterima pembeli, maka syarat ini fasid dan tidak berlaku. Apabila pembeli melihat adanya kecacatan maka dia boleh mengembailkannya, baik cacat pada bagian luar maupun dalam, baik barang itu berupa hewan maupun bukan. Mazhab syafi'i berpendapat apabila penjual mensyaratkan bebas dari cacat

${ }^{17} \mathrm{Ibid}, \mathrm{hlm} 436$ 
yang ada ketika akad, maka bisa jadi dia mensyaratkan bebas untuk dirinya sendiri atau untuk barang yang dijual, dalam hal ini hukum dari pensyaratan tersebut penjual tidak bebas dari akad, kecuali barang itu berupa hewan yang terdapat cacat pada bagian dalam yang tidak diketahui pada waktu akad, tetapi jika cacat itu terdapat pada bagian luar maka syarat tersebut tidak bermanfaat sehingga penjual harus bertanggung jawab atas cacat yang ada. Sedangkan mazhab Hanbali mengatakan, seseorang yang menjual barang dan mensyaratkan pada pembeli bahwa dia tidak bertanggung jawab atas cacat yang terjadi setelah akad sebelum diterima pembeli, maka syarat ini fasid dan tidak berlaku. Apabila pembeli melihat adanya kecacatan maka pembeli tersebut boleh mengembalikannya, baik cacat pada bagian luar maupun dalam, baik barang itu berupa hewan maupun bukan. ${ }^{18}$

Berdasarkan penjelasan di atas maka ada beberapa masalah yuridis dalam khiyar aibi yaitu:

1. Jika seseorang membeli barang dagangan yang mengandung cacat maka pembeli dapat menggunakan hak khiyar, mengembalikan tersebut dan mengambil uangnya, atau bisa juga membiarkan dengan kortingan harga.

2. Cara menentukan kortingan harga adalah membandingkan dengan barang dagangan yang tidak ada cacatnya dengan barang dagangan yang ada cacatnya, dan selisih harga yang akan menjadi kortingan harga barang cacat tersebut.

3. Jika terjadi peselisihan antara penjual dengan pembeli siapa yang menyebabkan aib, seperti jika seseorang membeli hewan, kemudian keesokan harinya pembeli mengklaim bahwa hewan yang sudah dibelinya ternyata pincang, atau jika seseorang membeli makanan kemudian rusak dan tidak mengerti siapa yang menyebabkannya, dalam hal ini yang dijadikan pegangan adalah

18 Ibid, hlm 438-439

http://dx.doi.org/10.18592/ sy.v18i2.2286 
klaim penjual dengan sumpah atau saling mengembalikan. ${ }^{19}$

Mengenai suatu barang yang dibeli, akan tetapi terdapat cacat atau rusak yang tidak terlihat pada bagian dalamnya, maka akab bai’ ini menjadi batal jika barang tidak dapat dimanfaatkan, dalam hal ini ulama fiqih sepakat bahwa penjual wajib mengembalikan semua uang pembayaran yang telah dibayarkan oleh pembeli. Ulama fiqih berbeda pendapat dalam hal jika ternyata barang yang rusak/cacat tersebut masih dapat dimanfaatkan.

Menurut mazhab Syafi'i, apabila barang yang rusak sebagian dan sebagian yang lainnya dapat dimanfaatkan, pembeli dapat mengembalikan dan mengambil kembali uang pembayaran, jadi pembeli tidak diminta tanggung jawab walaupun telah membelah atau membuka barang tersebut karena dia tidak mengetahui cacatnya. Pembeli harus mengembalikan barang yang bagiannya cacat/rusak walaupun ada bagian lain yang bisa dimanfaatkan dan mengambil uang yang telah dibayarkan.

19 Abdullah bin Muhammad ath Thayar et.al, 2004, Al-Fiqib Al-Musyassar Qismu alMuamalat, Mausuah Fiqhiyyah Hadisab Tatanawalu Abkam Al-Figh Al-Islami Bi Usblub Wadbih Li Al-
Sedangkan mazhab Maliki berpendapat barang yang tidak dapat diketahui cacat/rusaknya kecuali dengan membuka, membelah atau memecah maka pembeli tidak dapat mengembalikannya kecuali dengan adanya perjanjian antara penjual dengan pembeli. Akan tetapi, jika dalam masyarakat tidak ditemukan kebiasaan demikian, pembeli boleh mengembalikannya tanpa adanya perjanjian, dalam masalah ini menjadi landasan adalah urf (kebiasaan). Selain tidak boleh mengembalikan barang tersebut, pembeli juga tidak boleh meminta uang ganti rugi atas kerusakan barang tersebut.

Mazhab Hanafi berpendapat bahwa barang cacat yang tidak dapat diketahui kecuali dengan membuka, memecah atau membelahnya yang menyebabkan tidak dapat dimanfaatkan, maka akad bai' batal dan tidak sah sehingga penjual harus mengembalikan uang pembayaran. Namun jika sebagian barang itu masih dapat dimanfaatkan walaupun untuk

Mukhtashin Wa Ghairibim, edisi Indonesia, Ensiklopedi Fiqih Muamalah dalam Pandangan Empat Marhab, Yogyakarta: Maktabah Al- Hanif, hlm 117 
makanan hewan, maka pembeli tidak dimanfaatkan sama sekali maka pembeli boleh mengembalikannya, namun berhak untuk meminta uang ganti rugi pembeli mempunyai hak untuk meminta meskipun tidak dapat mengembalikan ganti rugi atas kekurangan yang ada dalam barang cacat tersebut kepada penjual. barang tersebut. Pembeli yang Besar kemungkinan dalam proses mengetahui adanya cacat pada barang pengembalain produk cacat akan ada yang dibeli tidak boleh memanfaatkannya, perselisihan diantara konsumen dengan jika dia memanfaatkan barang yang pelaku usaha sehingga menurut mazhab cacat/rusak tersebut maka pembeli tidak Syafi'i penjual dan pembeli yang mempunyai hak untuk mendapat ganti bersengketa mengenai masa terjadinya rugi.

Pendapat dari mazhab Hanbali adalah seseorang yang membeli barang, kemudian ditemukan kecacatan pada sebagian barang tersebut, sedangkan sebagian lainnya tidak, maka pembeli mempunyai hak untuk mengambil sebagian uang pembayaran atas kerusakan barang itu. apabila bagian dalam barang rusak namun setelah dibuka, dibelah atau dipecah barang itu tetap dapat dimanfaatkan, maka pembeli boleh memilih antara mengembalikan barang dengan membayar ganti rugi, atau membiarkan barang tersebut menjadi miliknya namun pembeli meminta ganti rugi terhadap penjual atas kecacatan barang tersebut. Akan tetapi jika ternyata barang yang cacat tadi tidak dapat kecacatan, apakah sudah lama atau baru terjadi dalam hal ini Imam Syafi'i membagi dalam lima pembahasan yaitu:

1. Penjual dan pembeli yang bersengketa dalam satu cacat yang mungkin baru terjadi atau sudah lama, dan masing-masing mungkin sudah benar. Apabila penjual menuduh bahwa cacat tersebut terjadi pada pembeli maka dia dibenarkan dengan adanya sumpah karena secara hukum asal adalah berlangsung akad tanpa ada kerusakan.

2. Penjual menjual barang dengan syarat bebas dari cacat, misalnya dia berkata "saya jual hewan ini dengan syarat saya tidak bertanggung jawab akan adanya cacat pada hewan ini" 
apabila hewan tersebut bebas dari cacat, kemudian terjadi cacat setelah akad sebelum diterima pembeli maka dia dapat mengembalikannya. Namun jika pembeli menuduh bahwa kecacatannya terjadi setelah akad sebelum diterima pembeli, tetapi penjual menyangkal dan mengatakan bahwa cacat itu adalah cacat yang lama di mana penjual tidak bertanggung jawab, maka yang dibenarkan adalah penjual dengan adanya sumpah.

3. Penjual dan pembeli bersengketa dalam dua cacat, menurut pembeli kedua cacat tersebut adalah cacat yang sudah lama terjadi, tetapi menurut penjual cacat yang satu adalah cacat yang baru terjadi, sedangkan yang satunya lagi adalah cacat yang sudah lama terjadi. Dalam hal ini, yang dibenarkan adalah pembeli dengan sumpahnya. Akan tetapi, jika pembeli tidak mau bersumpah maka dia tidak bisa mengembalikan barang yang cacat tersebut.

${ }^{20} \mathrm{Ibid}, \mathrm{hlm} 450-451$

http://dx.doi.org/10.18592/sy.v18i2.2286
4. Keadaan cacat itu menunjukkan bahwa dia adalah cacat yang sudah lama terjadi. Misalnya barang tersebut ada bekas luka yang telah sembuh dan barang itu baru saja dibeli dalam waktu satu hari. Dalam hal ini, yang dibenarkan adalah pembeli tanpa adanya sumpah.

5. Keadaan cacat menunjukkan bahwa dia adalah cacat yang baru saja terjadi. misalnya luka yang belum kering, sedangkan barang itu dibeli dalam waktu yang sudah lama, dalam hal ini yang dibenarkan adalah penjual tanpa adanya sumpah. ${ }^{20}$

Jika penjual dan pembeli berselisih tentang di tangan siapa cacat muncul, sedangkan keduanya tidak memiliki bukti, maka yang diterima adalah perkataan penjual disertai dengan sumpah. Sedangkan pendapat yang lain mengatakan bahwa yang diterima adalah perkataan pembeli disertai dengan sumpah, kemudian pembeli boleh mengambilkan barang cacat tersebut kepada penjual. ${ }^{21}$

\footnotetext{
${ }^{21}$ Sayyid Sabiq, op.cit, hlm 89
} 


\section{Kesimpulan}

Perlindungan terhadap konsumen merupakan salah satu kajian hukum yang paling dinamis baik dari sisi hukum positif maupun hukum Islam. Hal ini disebabkan karena perlindungan konsumen bersinggungan langsung dengan aktifitas perekonomian yang berkembang secara signifikan seiring dengan perkembangan zaman dan kemajuan teknologi. Interaksi konsumen dengan pelaku usaha adalah dalam jual beli, sehingga dalam hal hubungan antara konsumen dengan pelaku usaha memerlukan suatu aturan yang biasa disebut dengan fiqih jual beli. Konsep tentang perlindungan konsumen di dalam kajian fiqih jual beli tidak disebutkan secara jelas, akan tetapi prinsip-prinsip perlindungan konsumen dapat kita temukan di dalam sumbersumber hukum Islam seperti Al-Qur'an dan hadis yaitu perilaku Nabi Muhammad Saw dalam menjalankan parktik dagangnya.

Proses menjalankan transaksi jual beli seringkali kita temukan kesalahan baik dari pihak pelaku usaha ataupun konsumen, salah satu yang sering terjadi adalah ketika konsumen mendapati barang yang sidah belinya ternyata mengalami kerusakan atau cacat. Pada dasarnya Fiqih sebagai suatu tuntunan melarang Semua pelaku usaha untuk menjual barangnya yang cacat, tanpa menjelaskan kepada pembeli tentang kecacatan barang dagangan tersebut. Sehingga solusi yang ditawarkan fiqih jual beli dalam permasalahan ini adalah dengan cara melakukan hak khiyar aibi dimana ketentuannya adalah konsumen boleh mengembalikan barang yang dibelinya apabila pada barang tersebut terdapat suatu kecacatan, yang mengurangi kualitas barang atau mengurangi harganya. Namun jika konsumen sudah mengetahui kecacatan suatu produk tersebut kemudian dia ridha dengan hal tersebut maka akad jual beli tetap bisa dilanjutkan.

\section{Daftar Pustaka}

Arifin, Bey, 2015, Rangkaian Cerita AlQur'an Kisah Nyata Peneguh Iman, Jakarta: Zahira

Abdullah bin Muhammad ath Thayar et.al, 2004, Al-Fiqih Al-Musyassar Qismu al-Muamalat, Mausuah Fiqhiyyah Hadisab Tatanawalu 
232 Syariab: Jurnal Hukum dan Pemikiran, Volome 18, Nomor 2, Desember 2018, Hlm. 211-232.

Abkam Al-Figh Al-Islami Bi Usblub

Wadhih Li Al-Mukbtashin Wa

Ghairibim, edisi Indonesia,

Ensiklopedi Fiqih Muamalah dalam

Pandangan Empat Maŗab,

Yogyakarta: Maktabah Al- Hanif

Ash-Shiddiqy, Muhammad Hasbi, 1993

Falsafah Hukum Islam, Jakarta:

Bulan Bintang

Al-Utsaimin, Syaikh Muhammad Shalih, et. al, (penerjemah Saptono Budi

Satryo), 2008, Tanya Jawab

Lengkap Permasalaban Jual Beli,

Jakarta: Pustaka As-Sunnah.

Jusmaliani, 2008, Bisnis Berbasis Syariah,

Jakarta: Bumi Akasara

Kristiyanti, Celina Tri Siwi, 2001, Hukum

Perlindungan Konsumen, Jakarta:

Sinar Grafika

Khan, Muhammad Akram 1989,

Economic Teaching of Prophet

Mubammad, Islamabad: IIIE \&

IPS

Mustafa, Imam, 2016, Fiqih Mu'amalah Kontemporer, Jakarta: PT Raja Grafindo Persada.
Muchtar, Asmaji 2016, Dialog Lintas Mazbab Fiqh Ibadab \& Muamalah, Jakarta: Amzah

Rasjid, Sulaiman, 1998, Fiqih Islam, Bandung: Sinar Baru Algesindo

Schacht, Joseph 1964, An Introduction to Islamic Law, Oxford: University Press.

Syarifuddin, Amir, 1992, Pengertian dan Sumber Hukum Islam, dalam Falsafah Hukum Islam, Jakarta: Bumi Aksara.

Sabiq, Sayyid, 2013, Fiqih Sunnah jilid 5 (terj. Abu Syauqina Lc dan Abu Aulia Rahma Lc), Jakarta: Tinta Abadi Gemilang

Subekti, 1987, Aneka Perjanjian, Bandung: Alumni.

Zuhaili, Wahbah, 2007, Al-Fiqhul Islami wa Adillatubu, (terj. Abdul Hayyie Al-Kattani dkk), Jakarta: Gema Insani

Kompilasi Hukum Ekonomi Syari'ah 